\title{
Meningkatkan Skill Bahasa Inggris Mahasiswa Program Studi Sastra Inggris Fakultas Ilmu Budaya melalui Pembelajaran Debat Bahasa Inggris
}

\author{
Ni Luh Putu Krisnawati \\ Program Studi Sastra Inggris, Universitas Udayana \\ inacrisna@gmail.com
}

\begin{abstract}
Abstrak. Di era globalisasi ini, bahasa Inggris telah menjadi bahasa utama untuk pendidikan dan teknologi, bisnis, kesehatan, hukum dan lain-lain. Bahasa Inggris telah diakui oleh semua orang di dunia, jika mereka ingin bersaing dalam setiap aspek kehidupan yang harus mereka kuasai adalah bahasa Inggris. Peneliti dan guru diharuskan untuk menjadi kreatif dan inovatif dalam mengembangkan rencana pelajaran untuk belajar bahasa Inggris, salah satu cara untuk mengajar bahasa Inggris adalah dengan mengajarkan debat kompetitif dalam Bahasa Inggris. Debat adalah proses komunikasi dimana peserta diwajibkan untuk mengusulkan atau menentang suatu topik tertentu. Dalam melakukan debat, peserta atau yang dikenal sebagai pendebat harus memanfaatkan semua kemampuan mereka pada saat yang sama seperti kemampuan berbicara, keterampilan mendengar dan keterampilan berpikir kritis. Keterampilan ini sebenarnya adalah dasar untuk mengembangkan kemampuan dasar berbahasa Inggris. Oleh karena itu, tujuan dari penelitian ini (1) kemampuan skill berbahasa Inggris yang mana saja yang dapat dikembangkan dengan cara mengajar bahasa Inggris melalui latihan debat dan (2) apakah dengan mempelajari debat dapat secara signifikan mempengaruhi perkembangan Bahasa Inggris mahasiswa, dan (3) bagaimana cara mengajar Bahasa Inggris melalui praktik debat. Responden dari penelitian ini adalah siswa semester 1-3 Jurusan Bahasa Inggris, Universitas Udayana. Penelitian ini menggunakan metode deskriptif kualitatif dalam mendeskripsikan temuan dan metode observasi juga dilakukan untuk mengetahui peningkatan kemampuan bahasa Inggris yang dilakukan oleh siswa. Temuan menunjukkan bahwa belajar bahasa Inggris melalui praktik debat dapat memberi beberapa manfaat seperti berbagi pendapat tentang isu-isu tertentu, meningkatkan kepercayaan siswa untuk berbicara di depan umum, mengembangkan keterampilan bahasa, memperbaiki pemikiran kritis dan merangsang siswa intelektual untuk memecahkan masalah dan memberikan resolusi. Dan terakhir, temuan juga menunjukkan bahwa belajar bahasa Inggris melalui praktik debat dapat mengembangkan kemampuan berbicara, keterampilan mendengar, keterampilan membaca dan keterampilan menulis teks argumentatif.
\end{abstract}

Kata Kunci: debat, skill dasar bahasa inggris, pengajaran 


\section{PENDAHULUAN}

Dalam era globalisasi ini, masyarakat diberikan kebebasan dalam berkembang dan berevolusi. Sebagai akibat perkembangan ini, timbul banyak masalah di dalam masyarakat yang harus diselesaikan. Sebuah kemampuan berpikir kritis (critical thinking) sangatlah diperlukan untuk melihat suatu masalah secara lebih inovatif, rasional, dan menyeluruh, sekaligus memberikan peluang untuk menyelesaikan masalah dengan pertimbangan multi-perspektif.

Salah satu upaya untuk mengembangkan kemampuan berpikir kritis tersebut ialah melalui pengembangan kultur debat. Debat merupakan suatu kegiatan yang dilakukan oleh dua kelompok yaitu kelompok pro dan kontra dalam mendiskusikan dan memutuskan suatu masalah dan perbedaan. Sejatinya debat bukanlah tentang menang dan kalah, atau pro dan kontra terhadap mosi, namun pada hakikatnya, lomba berdebat adalah tentang menganalisis masalah dari berbagai sudut pandang, memunculkan ide ide baru, dan mencari solusi terbaik bagi pengambil kebijakan.

Dalam sebuah kultur debat, dibutuhkan beberapa kemampuan dan keilmuan yang dapat digunakan sebagai dasar untuk mengembangkan kultur tersebut lebih lanjut. Kepakaran dan kemampuan mengenai isu-isu sosial, politik, hukum, dan pembangunan dilihat sangat strategis sebagai modal awal untuk mengerti bagaimana dinamika masyarakat dan permasalahannya. Selain itu, dibutuhkan pula kemampuan berbahasa, terutama Bahasa Inggris, untuk mengkomunikasikan pandangan dan gagasan tersebut menjadi sebuah nilai yang dapat disebarkan secara verbal maupun non-verbal. Kemampuan komunikasi interpersonal juga menjadi penting untuk menghasilkan sebuah pandangan yang dapat dimengerti secara luas dan tersampaikan secara tepat

Di Universitas Udayana, Fakultas Ilmu Budaya, Program Studi Sastra Inggris menawarkan mata kuliah debat Bahasa Inggris. Dimana kegiatan pembelajaran mata kuliah debat melibatkan pemberian topik-topik tertentu untuk didiskusikan dan dicarikan solusinya. Akan tetapi, debat tidak saja hanya persoalan pemecahan msalah saja melainkan mata kuliah debat dapaat menjadi dasar untuk mengembangkan skill mahasiswa terutama skill Bahasa Inggris. Topik ini menarik untuk dikaji karena akan memberikan informasi mengenai kemampuan skill mana saja yang dapat dikembangan oleh debat, apa pengaruhnya terhadap kemampuan Bahasa inggris mahasiswa dan juga sebagai masukan dalam pemutakhiran silabus pengajaran mata kulaih debat.

Oleh karena itu, tujuan penelitian ini secara khusus adalah untuk mengetahui skill Bahasa Inggris apa saja yang dapat ditingkatkan melalui pengajaran debat bagi mahasiswa Program Studi Sastra Inggris, Fakultas Ilmu Budaya, Universitas Udayana. Tamuan dari penelitian ini juga akan mengidentifikasi pengaruh apa yang diberikan oleh pembelajaran debat terhadap kemampuan Bahasa Inggris mahasiswa. Selanjutnya, temuan dari penelitian ini 
juga akan mengidentifikasi masalah-masalah apa saja yang dihadapi oleh mahasiswa dalam melakukan debat.

\section{TINJAUAN PUSTAKA}

Bagian tinjauan pustaka ini membahas mengenai studi - studi terdahulu yang berhubungan dengan peningkata skill Bahasa Inggris. Studi - studi terdahulu yang masih dianggap relevan dengan penelitian ini dipaparkan secara mendetail sebagai berikut.

Dalam melakukan debat terdapat beberapa pokok skill yang teritegritasi yaitu: kemampuan berfikiran krtitis (critical thinking), kemampuan mendengarkan (listening), kemampuan menulis (writing), kemampuan berbicara (speaking). Untuk itulah Deards (2014) dalam artikelnya yang berjudul Making the Case for Teaching Students to Debate memaparkan cara terbaik untuk mengubah kurikulum agar membantu siswa menavigasi dunia yang berubah dengan cepat, Deards sangat menganjurkan agar setiap perubahan dalam kurikulum memasukan pelajaran debat dan penelitian mendukung perkembangan ini. Telah ditunjukkan bahwa siswa yang melakukan debat di tingkat universitas menunjukkan peningkatan kinerja akademis dan lebih sedikit masalah disiplin dan perilaku daripada non-debat. Debat dapat mendukung dan meningkatkan perkembangan otak sebagai kegiatan yang membutuhkan dan mengasah keterampilan ini.

Ada berbagai format debat, tapi semua berbagi berikut: struktur, peraturan dan prosedur, tim peserta, bergantung pada bukti, dan kebutuhan untuk membantah argumen yang diajukan. Menariknya, siswa yang melakukan umumnya tidak tahu apakah mereka harus pro ataupun kontra terhadap suatu topik. Ketidakpastian ini mengharuskan mereka untuk memikirkan masalah ini dengan pikiran terbuka dan, menyalurkan empati, untuk melihat bagaimana orang lain dapat mengajukan kasus yang mungkin tidak mereka yakini secara pribadi.

Oros (2007) dalam artikelnya Let's Debate: Active Learning Encourages Student Participation and Critical Thinking mengatakan bahwa Perdebatan kelas terstruktur (SCD), di mana tim siswa mendebat pertanyaan yang dipersiapkan di luar kelas, membantu memajukan dua tujuan yang diajarkan banyak instruktur ilmu politik untuk dicapai dengan siswa mereka: partisipasi kelas di luar "tersangka biasa" hadir di setiap kelas dan pemikiran kritis dan analisis isu politik Artikel ini menjelaskan metode yang digunakan oleh penulis dan beberapa rekan untuk mengenalkan SCD ke dalam beberapa jenis kursus sains politik berdasarkan pengalaman penulis yang luas dengan melakukan perdebatan semacam itu dalam berbagai kelas, dan kontribusi seperti pendekatan telah ditunjukkan pada pemahaman siswa. dan komunikasi isu-isu politik. Topik yang dibahas mencakup perbedaan dalam format debat dan persiapan untuk kelas dan ukuran kelas yang berbeda; bagaimana mengakomodasi siswa dengan kemampuan yang berbeda melalui tim dan manajemen peran yang efektif; pilihan penilaian/metode evaluasi; 
dan pendekatan untuk melibatkan seluruh kelas dalam latihan belajar aktif ini. Evaluasi juga diberikan berdasarkan analisis dan pengamatan komparatif penulis dan instruktur lain yang telah menggunakan pendekatan ini.

Permasalah tentang debat juga dipaparkan oleh Darby (2007) dalam artikelnya yang berjudul Debate: A Teaching-Learning Strategy for Developing Competence in Communication and Critical Thinking. Ia menguraikan masalah kompleks kebijakan kesehatan, politik, dan profesionalisme memerlukan strategi pengajaran yang melibatkan dan memotivasi mahasiswa pascasarjana dan undegraduate saat ini menjadi pemikir kritis dalam persiapan peran sebagai pemimpin, penyelenggara, dan advokat. Salah satu strategi, perdebatan, mewajibkan siswa untuk bekerja sebagai individu dan sebagai tim untuk meneliti isu-isu kritis, mempersiapkan dan menyajikan argumen logis, mendengarkan secara aktif berbagai perspektif, membedakan antara informasi subjektif dan objektif, mengajukan pertanyaan, mengintegrasikan informasi yang relevan, mengembangkan empati, kepercayaan proyek, berdasarkan pendapat berdasarkan bukti. Oleh karena itu, strategi debat dapat digunakan sebagai metode efektif untuk mencapai kompetensi yang disebutkan di atas dalam program sarjana.

Tumposky (2004) dalam artikelnya The debate debate mengemukakan bahwa debat memupuk kemampuan berpikir kritis siswa dan kesadaran akan pemikiran, dan memfasilitasi penalaran klinis dan kemampuan untuk berbagi sudut pandang dengan orang lain sambil mempelajari konten tertentu. Debat juga memungkinkan siswa untuk bergerak melampaui "hafalan belajar fakta, teori, dan teknik," dan memberi kesempatan untuk menerapkan pengetahuan melalui permainan peran sambil menunjukkan gagasan, nilai, dan sikap mereka. Namun, Tumposky juga memperingatkan bahwa debat dapat mengkompromi dan mendistorsi proses belajar, misalnya siswa dapat bekerja untuk menjadi efektif dalam mempengaruhi pemikiran orang lain dengan mengorbankan akurasi. Keterbatasan lain dalam debat adalah bahwa hal itu dapat menyebabkan frustrasi dan kecemasan pada beberapa peserta didik.

Semua studi yang disebutkan diatas sangat relevan dengan penelitian ini karena mereka memfokuskan penelitiannya pada pengajaran debat. Mereka menganalisabagaimana peran debat dalam pembelajaran. Untuk menghindari kemungkinan terjadinya plagiarism, penelitian ini berfokus pada skill Bahasa Inggris apa saja yang bias dikembangkan dengan pembelajaran debat, apakah ada implikasi yang signifikan terhadap perkembangan kemampuan Bahasa Inggris mahasiswa dan juga masalah apa saja yang dihadapi oleh mahasiswa ketika belajar debat. Penelitian ini juga akan menggunakan teori kooperatif guna mendeskripsikan masalah-masalah yang dihadapi mahasiswa ketika mengikuti pembelajarn debat. Definisi dari model pembelajaran kooperatif atau Cooperative Learning adalah rangkaian kegiatan belajar siswa dalam kelompok tertentu untuk mencapai tujuan pembelajaran yang dirumuskan. Terdapat tiga konsep sentral 
karakteristik pembelajaran kooperatif, sebagaimana dikemukakan oleh Slavin dalam Hamdani (1995), yaitu:

1. Penghargaan kelompok.

Pembelajaran kooperatif menggunakan tujuan kelompok untuk memperoleh penghargaan kelompok. Penghargaan ini diperoleh jika kelompok mencapai skor di atas kriteria yang ditentukan. Keberhasilan kelompok didasarkan pada penampilan individu sebagai anggota kelompok dalam menciptakan hubungan antarpersonal yang saling mendukung, membantu, dan peduli.

2. Pertanggungjawaban individu.

Keberhasilan kelompok bergantung pada pembelajaran individu dan semua anggota kelompok. Pertanggungjawaban tersebut menitikberatkan aktivitas anggota kelompok yang saling membantu dalam belajar. Adanya pertanggungjawaban secara individu juga menjadikan setiap anggota siap untuk menghadapi tes dan tugas-tugas lainnya secara mandiri tanpa bantuan teman sekelompok.

3. Kesempatan yang sama untuk mencapai keberhasilan.

Pembelajaran kooperatif menggunakan metode skorsing yang mencakup nilai perkembangan berdasarkan peningkatan prestasi yang diperoleh siswa dari yang terdulu. Dengan menggunakan metode skorsing ini siswa yang kesempatan untuk berhasil dan melakukan yang terbaik bagi kelompoknya.

\section{METODE}

Metode penelitian merupakan langkah - langkah yang diambil dalam sebuah penelitian ilmiah. Langkah - langkah tersebut menjadi penting untuk memastikan penelitian berlangsung secara akademis. Dalam pelaksanaan penelitian ini maka metode penelitian yang akan diterapkan dibagi menjadi tiga bagian yaitu sumber data, metode dan teknik pengumpulan data, serta metode dan teknik analisa data.

Sumber data dalam penelitian ini adalah informasi yang didapatkan dari kuesioner yang didistribusikan kepada responden: (1) mahasiswa sebanyak 31 mahasiswa yang berada di semester 1 sampai 3, (2) Empat pengajar Bahasa Inggris yang biasa ditugaskan mengajar mata kuliah debat. Selain kuesioner, juga akan dilakukan interview kepada responden.

Kuesioner disebarkan kepada responden bisa memberikan informasi mengenai pengajaran debat seperti tersebut di atas. Dalam kuesioner terdapat pertanyaan tertutup, di mana responden diminta memilih jawaban yang sudah tersedia; selain itu juga terdapat pertanyaan tertutup di mana responden diminta memberikan tambahan informasi sesuai dengan pengalaman pribadi masingmasing. Interview akan dilakukan untuk mengumpulkan informasi yang lebih mendetil yang tidak bisa dijaring menggunakan kuesioner.

Metode yang akan digunakan saat analisa data adalah metode deskriptif kualitatif. Metode deskriptif kualitatif menerapkan teknik deskripsi saat dilakukan 
analisa data berdasarkan jawaban dari kuesioner. Dengan begitu akan terlihat bagaimana manfaat yang didapatkan oleh mahasiswa. Data dari interview dengan responden akan mendukung deskripsi yang didapatkan dari kuesioner.

\section{HASIL DAN PEMBAHASAN}

Bagian ini akan mendiskripsi jawaban yang dikemukan oleh mahasiswa setelah mengikuti kelas debat sebanyak 15 kali pertemuan. Adapun pertanyaan-pertanyaan dalam kuesioner sebagai berikut:

1. Menurut pendapat kalian skill Bahasa Inggris apa saja yang berkembang setelah mendapatkan pelatihan debat? Beri alasan.

2. Sebutkan setidaknya tiga manfaat dari pembelajaran debat?

3. Masalah apa saja yang dihadapi ketika mempraktekan debat?

\section{Skill Bahasa Inggris yang Ditingkatkan melalui Pembelajaran Debat Bahasa Inggris}

Masalah pertama dalam penelitian ini adalah untuk mengetahui skill Bahasa Inggris apa saja yang ditingkatkan oleh pembelajaran debat Bahasa Inggris yang berhubungan dengan kemampuan dasar dalam penguasaan Bahasa Inggris. Pertanyaan dalam kuesioner untuk menganalisa masalah ini diberikan kepada ke dua kelompok responden, yaitu mahasiswa dan juga kepada pengajar mata kuliah debatBahasa Inggris di Program Studi Sastra Inggris, Fakultas Ilmu Budaya, Universitas Udayana.

Pertanyaan yang berhubungan dengan masalah penelitian pertama adalah mengenai kemampuan berbahasa Inggris dasar yang mana saja yang dirasakan telah meningkat oleh mahasiswa setalah diberikan pembelajaran debat Bahasa Inggris. Responden diminta memberikan nilai kepada daftar peningkatan dalam penguasaan kemampuan dasar Bahasa Inggris yang disediakan dalam tabel. Nilai yang diberikan mempunyai rentangan dari $1=$ kurang, $2=$ sedang, $3=$ meningkat.

Nilai dari pengajar mahasiswa dapat dilihat pada tabel berikut ini:

Tabel 1 Kemampuan dasar bahasa Inggris yang dianggap meningkat oleh mahasiswa setelah mendapatkan pembelajaran debat bahasa Inggris

\begin{tabular}{|l|l|}
\hline \multicolumn{1}{|c|}{ Keahlian } & \multicolumn{1}{c|}{ Nilai } \\
\hline Membaca & 3 \\
\hline Mendengar & 3 \\
\hline Berbicara & 3 \\
\hline Menulis & 3 \\
\hline
\end{tabular}




\begin{tabular}{|l|l|}
\hline Tata Bahasa & 2 \\
\hline Kosa Kata & 2 \\
\hline Pengucapan & 2 \\
\hline
\end{tabular}

Dari tablel diatas, mahasiswa berpendapat bahwa kemampuan dasar berbicara (speaking), membaca (reading), mendengarkan (listening) dan menulis (writing) adalah kemampuan dasar Bahasa Inggris yang paling meningkat. Hal ini diperkuat oleh alasan mahasiswa sebagai berikut:

Kemampuan membaca meningkat karena dalam melaksanakan praktik debat Bahasa Inggris mahasiswa diberikan berbagai topik mengenai isu terkini yang ada di dunia seperti misalnya mengenai robot yang bernama Sophia yang diberikan kewarganegaraan oleh Arab Saudi. Untuk mengatahui segala informasi mengenai robot Sophia tersebut mahasiswa harus rajin berselancar di Google dan membaca artikel terkait robot Sophia sehingga mahasiswa terlatih untuk menggunakan metode scanning dan skimming. Dan karena terbiasa dengan menggunakan metode scanning dan skimming tersebut, otomatis mahasiswa mampu mejelajahi berbagai artikel dalam waktu yang singkat guna mengumpulkan informasi yang berguna yang berhubungan dengan topik debat yang diberikan.

Kemampuan berbicara (speaking) juga mengalami peningkatan karena dalam melakukan praktek debat mahasiswa diharuskan uituk berbicara menggunakan bahasa inggris selama kurang lebih tujuh menit sehingga mahasiswa setiap hari berlatih menggunakan bahasa inggris untuk menyampaikan ide-ide dari topik debat tersebut.

Skill berikutnya yang dianggap mengalami penigkatan adalah kemampuan mendengarkan, karena dalam praktek debat mereka harus mendengarkan untuk mencatat argumen dan ide apa saja yang telah disampaikan oleh tim lawan, sehingga nantinya mereka bisa dengan mudah menyanggap apa-apa saja argumen dari tim lawan.

Kemampuan menulispun dirasakan meningkat oleh mahasiswa karena dalam praktek debat mahasiswa diwajibkan untuk menuliskan ide mereka terhadap topik secara terstruktur dan mereka dilatih untuk membuat paragraf argumentatif.

Hal senada juga disampaikan oleh para pengajar debat Bahasa Inggris di Program Studi Sastra Inggris Fakultas Ilmu Budaya melalui tabel berikut ini: 


\section{Tabel 2 Kemampuan dasar bahasa Inggris yang dianggap meningkat oleh para pengajar setelah mendapatkan pembelajaran debat Bahasa Inggris}

\begin{tabular}{|c|c|}
\hline Keahlian & Nilai \\
\hline Membaca & 3 \\
\hline Mendengar & 3 \\
\hline Berbicara & 3 \\
\hline Menulis & 3 \\
\hline Tata Bahasa & 2 \\
\hline Kosa Kata & 2 \\
\hline Pengucapan & 2 \\
\hline
\end{tabular}

Dari tabel diatas dapat dilihat bahwa menurut para pengajar rata-rata mahasiswa sudah mengalami peningkatan untuk skill membaca (reading), mendengar (listening), berbicara (speaking), dan menulis (writing) hal ini disebabkan oleh latihan secara terus menurus dan berkelanjutan dan juga debat memaksa mereka untuk berlatih karena terikat oleh aturan dari sistem debat Bahasa Inggris tersebut.

\section{Manfaat yang Didapat setelah Pembelajaran Debat Bahasa Inggris}

Selanjutnya adapun beberapa manfaat yang didapatkan oleh mahasiswa setelah melakukan praktek debat Bahasa Inggris, yaitu:

\section{Berfikir kritis}

Dalam debat mahasiswa merasa dilatih untuk berfikir kritis yaitu bisa melihat suatu masalah dari semua posisi baik pro dan kontra. Misalnya jika dalam debat mosinya Adalah tenten hukuman mati untuk korupter. Jika berada pada posisi pro, mahasiswa akan mengangap bah hukuman mati itu perlu, karena para koruptor selain merugikan negara tetapi juga menyengsarakan masyarakat, sedangkan jika berada pada posisi kontra, mahasiswa mengangap bahwa hukuman mati tidak layak diberikan karena itu bertentangan dengan hak asasi manusia.

\section{Percaya diri berbicara di depan umum}

Dalam melakukan praktik debat, mahasiswa akan terbiasa berbicara di depan umum atau melakukan public speaking. Aktifitas ini akan melatih percaya diri mahasiswa 
karena mahasiswa selalu dilatih untuk berbicara di depan orang banyan setiap kali mereka mengemukakan argumen ataupun ide mereka.

\section{Meningkatkan kemampuan berbahasa Inggris}

Hal ini berhubungan dengan masalas 1 diatas, iya, dennen melakukan praktik debat Bahasa inggris mahasiswa akan data meningkatkan kemampuan berbahasa inggrisnya. Karena dalam melakukan praktik debat Bahasa Inggris skill seperti reading, speaking, listening dan writing digunakan. Dan karena seringnya berlatih, kemampuan bahasa Inggrispun meningkat.

\section{Kaya akan ilmu pengetahuan}

Dalam melakukan praktik debat, mahasiswa dituntut untuk mengetahui informasi terbaru dari berbagai hal yang berkaitan dennen mooi misalnya pengetahuan dalam dunda pendidikan, kesehatan, ekonomi, sosial budaya, hukum, pariwisata bankan politik. Hal ini memaksa mahasiswa untuk membaca sebanyak mungkin guna mengumpulkan informasi yang mereka butuhkan dan membuat mereka kaya akan ilmi pengetahuan.

\section{Dapat mengambil keputusan yang tepat}

Mahasiswa meresa mereka dapat memberikan solusi yang tepat untuk masalahmasalah yang ada. Karena dalam praktik debat bahasa Inggris, mahasiswa dilatih untuk membuat kebijakan-kebijakan yang menguntungkan untuk rakyat dan memberikan solusi untuk maslah yang ada. Misalnya, jika mosi debat itu menginginkan mahasiswa untuk berdepat tentang pemimdahan ibukota di Indonesia, mahasiswa harus memberikan solusi kemana akan dipindahkan, dan mengapa harus dipindahkan.

\section{Masalah yang Dihadapi Ketika Melakukan Pembelajaran Debat}

Dalam melakukan pratik debat Bahasa Inggris mahasiswa merasa masalah utama yang belim mereka atası adalah penggunaan AREL dalam bidat. AREL adalah kemampuan berfikir kritis yang terstuktur sehingga argument yang dikemukan jelas. Dalam melakukan AREL mahasiswa harus mempunyai alasan kenara bisa pro ataupun kontra, lalu berisikan bukti-bukti yang kongkret yang mendukung argument tersebut dan menyimpulkan argument tersebut sehingga berhubungan dengan mosi yang diberikan.

\section{KESIMPULAN}

Dari pembahasan diatas, data disimpulkan bahwa debat bahasa Inggris merupakan salah satu cara pembelajaran yang data meningkatkan kemampuan Bahasa inggris mahasiswa, selain kemampuan bahasa inggris mahasiswa yang meningkat debat Bahasa Inggris juga memberikan maniata yang bank kepada mahasiswa yaitu 
dengan melakukan praktik debat, mahasiswa bisa berfikiran kritis dan cepat, mamhasiswa mampu membuat keputusan yang tepat dan memberikan solusi terhadap suatu masalah dan kaya akan ilmi pengetetahuan. Akan tetepi, mahasiswa juga meras masalah terbesar dalam debat adalah menggunakan metode AREL yaitu argument, reasoning, evidence dan link-back. 


\section{DAFTAR PUSTAKA}

Garrett M, Schoener L, Hood L. (1996). Debate: A teaching strategy to improve verbal communication and critical-thinking skills. Nurse Education. 21: 3748.

Tumposky NR. (2004). The debate debate. The Clearing House. 78: 42-55.

Elliot LB. (1993). Using debates to teach the psychology of women. Teaching Psychol. 20(1): 35-38.

Moeller TG. (1985). Using classroom debates in teaching developmental psychology. Teaching Psychol. 12(4): 207-209.

Combs HW, Borne G. (1989). The impact of marketing debates on oral communication skills. Bulletin. 52(2): 21-25.

Freely AJ. (1986). Argumentation and debate. (6thed). Belmont, CA: Wadsworth Co. 248-251.

Griswold LS. (1999). Debate as a teaching strategy. The American Journal of Occupational Therapy. 54: 427-428.

Pernecky M. (1997). Debate for the economics class-and others. College Teaching. 45: 136-138.

Hamdani. (2011). Strategi belajar mengajar. Bandung: Pustaka Setia 